\title{
MANAJEMEN SUMBER DAYA MANUSIA STRATEGIK, KINERJA KARYAWAN DAN KINERJA PEMASARAN (Pada Industri Pengolahan buah markisa Di MAKASSAR)
}

\author{
Rukiaty Usman \\ Staf Pengajar FAPERTA UMMU-Ternate, $\boldsymbol{e}$-mail: -
}

\begin{abstract}
ABSTRAK
Indonesia sebagai negara tropis memiliki potensi besar untuk dapat menghasilkan aneka macam buah. Buah-buahan Indonesia yang mempunyai potensi untuk dikembangkan menjadi produk olahan adalah buah-buahan lokal. Salah satunya adalah buah markisa. Penelitian ini bertujuan untuk Mengetahui aplikasi dan menganalisa adanya pengaruh dari praktik-pratik menejemen sumber daya strategik yang meliputi training, selective staffing, empowerment dan performance appraisal terhadap kinerja karyawan dan kinerja pemasaran pada industry pengolahan buah markisa di Makassar. Peneltian ini dilaksanakan dari Oktober sampai Desember 2011, dengan menggunakan metode analisis swot. Hasil analisis strategi swot yaitu : Strategi (SO) meningkatkan volume produksi, Strategi (WO) peningkatan kelembagaan industry pengolahan, Strategi (ST) menetapkan strategi harga, (WT) memantapkan rencana pemasaran dan mutu pelayanan konsumen.
\end{abstract}

\section{Kata Kunci: Analisis Swot, Buah Markisa}

\section{PENDAHULUAN}

\subsection{Latar Belakang}

Indonesia sebagai negara tropis memiliki potensi besar untuk dapat menghasilkan aneka macam buah. Berbagai jenis buah utama yang dihasilkan oleh Indonesia dan mempunyai potensi untuk dikembangkan menjadi produk olahan, seperti buah dalam kaleng, minuman sari buah, manisan buah selai dan produk olahan buah lainnya. Produksi buah nasional tahun 2007 sebesar 15,84 juta ton. Buah-buahan Indonesia yang mempunyai potensi untuk dikembangkan menjadi produk olahan adalah buah-buahan lokal. Salah satunya adalah buah markisa.

Markisa (Passiflora sp) sebenarnya bukan tanaman asli hasil budidaya di Indonesia, Markisa berasal dari daerah tropis dan subtropis di Amerika. Buah markisa yang ada di Indonesia ada beberapa jenis antara lain adalah markisa sayur atau erbis (Passiflora guadrangularis), konyal (Passiflora lingularis), markisa ungu atau siuh (Passiflora edulis f. edulis) dan markisa kuning (passiflora edulis f. flavicarpa). Dari keempat jenis buah markisa ini yang banyak dibudidayakan adalah markisa ungu atau siuh. Hal ini disebabkan karena sari buah markisa ungu mempunyai cita rasa manis-asam dengan aroma yang khas.

Tanaman markisa di Propinsi Sulawesi Selatan sebagian besar tanaman adalah dari varietas markisa ungu (Passiflora edulis). Varietas ini sangat rentan terhadap nematoda, perakarannya dangkal dan musim buahnya pada bulan-bulan tertentu. Kondisi tersebut merupakan salah satu penyebab rendahnya produktivitas markisa. Musim panen buah markisa pada umumnya dari bulan November sampai dengan bulan April tahun berikutnya, dengan puncaknya pada bulan Desember sampai Januari, kemudian sesudah bulan April, praktis tidak ada buah. Namun demikian di Sulawesi Selatan telah dikembangkan sambung batang antara tanaman markisa varietas edulis sebagai batang atas dan varietas flavicarpa sebagai batang bawah. Keunggulan dari sistem penyambungan tersebut adalah bahwa varietas flavicarpa mempunyai perakaran dalam, batang lebih besar dan tahan terhadap nematoda. Dengan kondisi tersebut, 


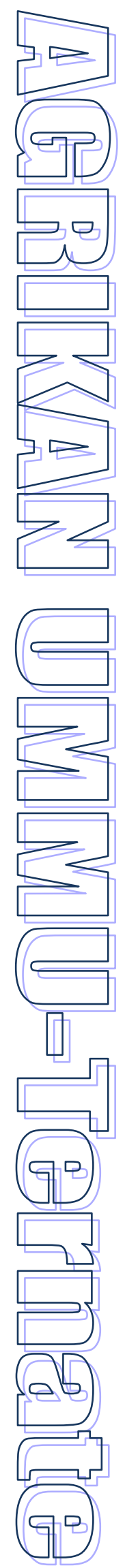

tanaman markisa dapat berbuah sepanjang tahun, sehingga produktivitasnya meningkat 20 - 30 ton buah/ha per tahun. Sementara itu, jika hanya dari varietas edulis saja, maka produktivitas hanya 5 10 ton buah/ha per tahun. Dengan teknik penyambungan tersebut diharapkan produksi markisa di Indonesia akan meningkat dan tersedia sepanjang tahun

Markisa bisa menjadi tanaman budidaya alternatif bagi petani dan secara ekonomis bisa menambah pendapatan bagi petani dan kemudian jika di tanam secara massal akan menghidupkan sektor industri (Sirup Markisa) yang tentunya menambah pendapatan negara (pajak), lapangan kerja. Untuk keluarga petani dan lingkungan sekitar, buah tanaman markisa yang kaya vitamin $\mathrm{C}$ akan dapat membantu keluarga petani menjaga stamina jika di konsumsi sendiri secara langsung, karena rasanya yang enak dan masih dalam bentuk segar. (Andreas, 2008).

Usia tanaman yang sudah tua dan cara pengelolaan yang kurang baik menjadi pemicu utama produksi buah markisa anjlok. Bahkan, tahun ini dipatok maksimal 20 ribu ton, jauh dari potensi yang sesungguhnya. Data Dinas Pertanian Tanaman Pangan dan Hortikultura Sulawesi Selatan, menyebutkan di daerah ini terdapat 25.399 hektare lahan yang potensial untuk pengembangan markisa. Sayangnya, baru 4.411 hektare yang ditanami. Potensi produksinya sekira 34.226 ton (Anonim, 2009).

Anjloknya produksi markisa di tengah tingginya permintaan mendorong pihak Dinas Pertanian Tanaman Pangan dan Hortikultura Sulsel terus mencari cara untuk meningkatkan produksi dan kualitas. Tetapi tidak bisa dalam waktu singkat, butuh waktu untuk meningkatkan produksi guna memenuhi permintaan industri pengolahan markisa di Makassar. Berbagai upaya yang dilakukan diharapkan mampu mengatrol volume produksi. Jika pada tahun lalu, jumlah ekspor Markisa Sulsel 14 ribu ton. Maka diharapkan tahun ini bisa naik menjadi 18 ribu ton hingga 20 ribu ton. Sulsel sebetulnya berpotensi menghasilkan markisa sampai 34.226 ton per tahun. Kendala utama sehingga permintaan markisa ini belum mampu dipenuhi, karena minimnya bahan baku seperti semakin berkurangnya tanaman markisa akibat sudah tua, yang berakibat beberapa tahun terakhir ini produksi markisa di Sulsel anjlok.

Dibanding musim panen sebelumnya, produksi markisa pada musim panen akhir 2008 turun hingga 30 persen. Rata-rata, produksi markisa Sulsel saat ini tinggal 6,4 ton hingga 7 ton. Akibat anjloknya produksi markisa Sulsel, informasi yang diperoleh Dinas Pertanian Tanaman Pangan dan Hortikultura Sulsel, sudah ada beberapa pabrik sirup markisa yang tutup karena kekurangan bahan baku (Anonim, 2009).

Pemasaran adalah suatu proses sosial dan manajerial di mana individu dan kelompok mendapatkan kebutuhan dan keinginan mereka dengan menciptakan, menawarkan dan bertukar sesuatu yang bernilai satu sama lain. Definisi ini berdasarkan pada konsep inti, yaitu : kebutuhan, keinginan dan permintaan; produk, nilai, biaya dan kepuasan; pertukaran, transaksi dan hubungan; pasar, pemasaran dan pemasar. Adapun tujuan pemasaran adalah mengenal dan memahami pelanggan sedemikian rupa sehingga produk cocok dengannya dan dapat terjual dengan sendirinya. Idealnya pemasaran menyebabkan pelanggan siap membeli sehingga yang tinggal hanyalah bagaimana membuat produknya tersedia. Sedangkan proses pemasaran terdiri dari analisa peluang pasar, meneliti dan memilih pasar sasaran, merancang strategi pemasaran, merancang program pemasaran, dan mengorganisir, melaksanakan serta mengawasi usaha pemasaran (Ilmanoz, 2008).

Strategi pemasaran adalah serangkaian tindakan terpadu menuju keunggulan kompetitif yang berkelanjutan. Faktor-faktor yang mempengaruhi strategi pemasaran adalah (1) faktor mikro, yaitu perantara pemasaran, pemasok, pesaing dan masyarakat, (2) faktor makro, yaitu demografi/ekonomi, politik/hukum, teknologi/fisik dan sosial/budaya. Sedangkan strategi dan kiat pemasaran dari sudut pandangan penjual (4 P) adalah tempat yang strategis (place), produk yang bermutu (product), harga yang kompetitif (price) dan promosi yang gencar (promotion). Sedangkan dari sudut pandang pelanggan (4 C) adalah kebutuhan dan keinginan pelanggan (customer needs and wants), biaya pelanggan (cost to the customer), kenyamanan (convenience) dan komunikasi (comunication). Tujuan akhir dan konsep, kiat dan strategi pemasaran adalah kepuasan pelanggan sepenuhnya ("total Customer Statisfaction"). Kepuasan pelanggan sepenuhnya bukan berarti memberikan kepada apa yang menurut kita keinginan dari mereka, tetapi apa yang sesungguhnya mereka inginkan serta kapan dan bagaimana mereka inginkan. Atau secara singkat adalah memenuhi kebutuhan pelanggan (Ilmanoz, 2008).

Strategi sumber daya manusia juga di perlukan dalam suatu industri dalam hal ini 


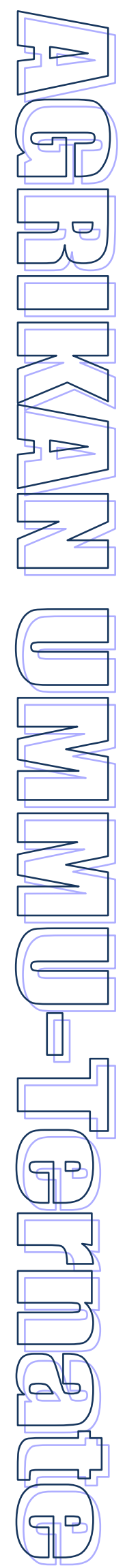

perusahaan industri-industri pengolahan buah markisa di Sulawesi Selatan. Semakin baik budaya perusahaan tersebut, semakin mudah organisasi mencapai sukses, sebaliknya semakin buruk budaya organisasi perusahaan maka semakin sulit organisasi membangun sukses.

Kesuksesan dan kegagalan perusahaan atau organisasi, dapat dilihat melalui beberapa indikator, diantaranya berupa hasil penjualan pangsa pasar, ukuran aset, peneriman dan investasi, pengembangan barang dan jasa baru, jaringan penjualan dan pengembangan pasar. Implikasi adalah perusahaan atau organisasi perlu menyesuaikan rencana strategis SDM dengan keberhasilan/kemajuan

kegagalan/kemunduranyang terjadi.

Seiring dengan terjadinya kemajuan atau kemunduran perusahaan, maka perusahaan harus menyesuaikan diri dengan tujuan perusahaan, apakah akan dikembangkan atau dikurangi. Jika tujuan perusahaan dikembangkan/ditingkatkan, maka SDM juga perlu ditingkatkan. Sebaliknya, jika perusahaan mengurangi tujuan perusahaan, maka SDM juga harus mengikutinya.

\subsection{Tujuan Penelitian}

Sesuai dengan permasalahan di atas tujuan dari penelitian adalah:

1. Mengetahui aplikasi dari praktik-praktik manajernen sumber daya strategik yang meliputi training, selectif staffing, empowerment dan performance appraisal terhadap kinerja karyawan pada industry pengolahan buah markisa di Makassar.

2. Menganalisis pengaruh variabel praktikpraktik manajemen sumber daya strategik yang meliputi sub variabel training, selective stqffing, empowerment dan performance appraisal terhadap variabel kinerja pemasaran.

\section{METODE PENELITIAN}

\subsection{Tempat dan Waktu Penelitian}

Penelitian ini dilaksanakan di kota Makassar propinsi Sulawesi Selatan, pada bulan Oktober sampai Desember 2011. Lokasi ini dipilih karena kota Makassar merupakan sentra produksi dan terdapat industry pengolahan buah markisa.

\subsection{Jenis dan Sumber Data}

Data yang digunakan pada penelitian ini adalah data primer dan data sekunder. Data primer diperoleh secara langsung atau observasi dan wawancara menggunakan quisioner di industry pengolahan buah markisa yang ada dikota Makassar. Data sekunder diperoleh di kantor atau instansi yang terkait dengan penelitian ini di kota Makassar.

\subsection{Metode Pengambilan Data}

Metode yang digunakan dalam pengambilan data pada penelitian ini langsung ke industry pengolahan buah markisa Makassar.

\subsection{Metode Analisis Data}

Analisis data yang digunakan adalah dengan menggunakan Analisis SWOT yaitu suatu analisa mendalam mengenai suatu bisnis baik sumber daya yang dimilikinya maupun lingkungannya. SWOT Analisis adalah suatu proses yang penting dan merupakan tahap yang harus dilakukan dalam proses manajemen strategi. Dimana analisis SWOT ini melihat peluang, ancaman, kekuatan dan kelemahan dari perusahaan (Rangkuti, 2003).

Analisis SWOT adalah identifikasi berbagai faktor secara sistematis untuk merumuskan strategi perusahaan. Cara membuat analisis SWOT, penelitian menunjukkan kinerja perusahaan dapat ditentukan oleh kombinasi faktor internal dan eksternal. Kedua faktor tersebut harus dipertimbangkan dalam analisis SWOT. SWOT adalah singkatan dari lingkungan internal Strenghts dan Weaknesses serta lingkungan eksternal Opportunities dan Threats yang dihadapi dunia bisnis (Rangkuti, 2003).

\section{HASIL DAN PEMBAHASAN \\ 3.1. Budidaya Markisa}

Buah markisa mempunyai nilai ekonomis yang tinggi, karena dapat dijadikan minuman segar yang menyehatkan. Sari buahnya sehat dikonsumsi segala usia, karena mengandung vitamin $\mathrm{C}$ dan antioksidan. Markisa ungu (Passiflora edulis) cocok ditanam di dataran tinggi dan markisa kuning (Passiflora flavicarva) di dataran rendah (Anonim, 2008).

Menanam markisa tidaklah sulit. Perawatannya mudah. Kita bisa menanamnya di lahan kosong. Misalnya di halaman depan atau belakang rumah. Markisa berdaun lebar, batangnya kecil, langsing dan panjang. Hidupnya merambat dengan bantuan sulur berbentuk spiral. Sedangkan bunganya hermafrodit (berkelamin dua) dan baunya harum. Penyerbukannya silang dengan atau tanpa bantuan lebah madu (Anonim, 2008).

Di samping itu, tanaman markisa termasuk tanaman yang tidak tahan terhadap kondisi lahan yang basah. "Bibitnya dapat mengunakan biji 


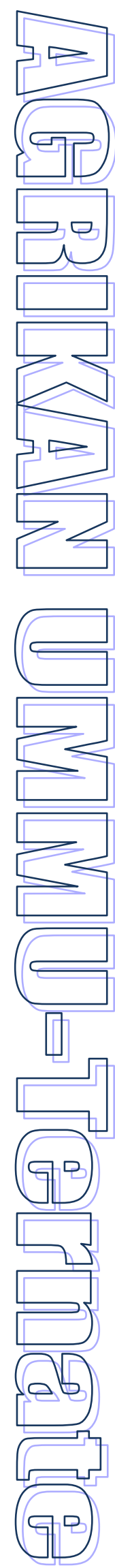

atau stek batang, yang sebaiknya disemaikan dahulu. Dipindahkan setelah tingginya lebih dari 0,5 meter atau sudah berdaun 3-4 helai. Lahan yang akan digunakan sebaiknya terbuka, dicangkul untuk menghilangkan gulma dan alang-alang. Selanjutnya dibuat lubang berukuran $40 \mathrm{~cm}$ X $40 \mathrm{~cm}$, kedalamannya 30-40 cm. Lalu diberi pupuk kandang kira-kira $10 \mathrm{~kg}$. Jarak tanam antar pohon berkisar 2 x 5 meter.

Waktu penanaman paling baik dilakukan menjelang musim kemarau. Sebab biasanya bunganya cepat keluar, kira-kira enam bulan. Kalau di tanam menjelang musim hujan, bunga akan keluar menjelang bulan ke sepuluh hingga ke duabelas.

Tanaman markisa dapat dirambatkan pada pohon hidup atau kayu Gliricidia. Markisa yang dirambatkan dengan sistem pagar produksinya lebih tinggi. Untuk menjalarkan batang markisa, digunakan kawat yang dibentangkan mendatar seperti pada perambatan tanaman anggur. Pemeliharaannya dengan pemberian pupuk NPK (15:15:15) sebanyak 25-100 g per tanaman, tergantung umurnya. Setelah bibit yang ditanam di sepanjang pagar (jarak 2-3 m) mencapai bentangan kawat terbawah, ujung bibit segera dipangkas. Dipilih tiga tunas yang kekar. Dua tunas dijalarkan pada bentangan kawat terbawah dan satu lagi dibiarkan tumbuh mencapai bentangan kawat di atasnya (Anonim, 2008).

\subsection{Teknologi Produksi}

Teknologi produksi yang dikemukakan di sini adalah teknologi pengolahan buah markisa menjadi sirup markisa, sebagaimana yang dilakukan selama ini (dikutip dari Buletin Teknopro Hortikultura, No. 70, Juni 2004). Beberapa tahapan dalam proses produksi sirup markisa adalah sebagai berikut :

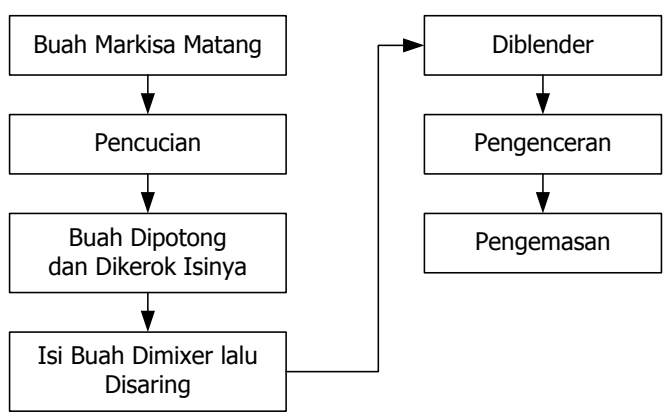

\section{Gambar 1. Proses Produksi Sirup Markisa}

Dalam rangka pengembangan sistem jaminan mutu guna mewujudkan pemasaran hasil hortikultura yang berdaya saing, maka dilakukan standarisasi buah markisa. Hal ini dimaksudkan agar ada penentuan tingkat kualitas buah markisa, termasuk keseragaman kualitas markisa yang dipasarkan produsen kepada konsumen. Adapun tujuannya adalah untuk meningkatkan peluang pasar yang lebih luas dengan mendapatkan harga jual yang lebih layak yang pada akhirnya juga akan dinikmati pelaku usaha, termasuk adanya peningkatkan pendapatan petani sendiri.

\subsection{Kendala Dalam Pemasaran Markisa}

Usia tanaman yang sudah tua dan cara pengelolaan yang kurang baik menjadi pemicu utama produksi buah markisa anjlok. Bahkan, tahun ini dipatok maksimal 20 ribu ton, jauh dari potensi yang sesungguhnya. Data Dinas Pertanian Tanaman Pangan dan Hortikultura Sulawesi Selatan, menyebutkan, di daerah ini terdapat 25.399 hektare lahan yang potensial untuk pengembangan markisa. Sayangnya, baru 4.411 hektare yang ditanami. Potensi produksinya sekitar 34.226 ton (Anonim, 2009).

Anjloknya produksi markisa di tengah tingginya permintaan mendorong pihak Dinas Pertanian Tanaman Pangan dan Hortikultura Sulsel terus mencari cara untuk meningkatkan produksi dan kualitas. "Tetapi tidak bisa dalam waktu singkat, butuh waktu untuk meningkatkan produksi guna memenuhi permintaan industri pengolahan markisa di Makassar. Berbagai upaya yang dilakukan diharapkan mampu mengatrol volume produksi. Jika pada tahun lalu, jumlah ekspor Markisa Sulsel 14 ribu ton. Maka diharapkan tahun ini bisa naik menjadi 18 ribu ton hingga 20 ribu ton. "Sulsel sebetulnya berpotensi menghasilkan markisa sampai 34.226 ton per tahun (Anonim, 2009).

Buah Markisa asal Sulsel ini menghasilkan sari yang manis alami. Karena itu, permintaannya terus meningkat, namun belum mampu dipenuhi karena terkendala budidaya produksi, sehingga pasokan bahan baku tidak kontinyu karena produksi markisa bersifat musiman, konsistensi mutu dan ukuran serta tingkat kematangan buah tidak merata disebabkan masih terbatasnya investasi budidaya perkebunan buah skala komersial. Terbatasnya penanganan teknologi pasca panen produksi, dan kurangnya promosi baik dalam negeri maupun luar negeri. Meski demikian, Sulsel selalu rutin mengirim markisa ke Australia dalam bentuk setengah jadi. Selain Sulsel, pasar markisa dunia juga diisi sejumlah negara produsen markisa yang menjadi pesaing Sulsel. Di antaranya Brasil, Kolombia, Ekuador, Peru, Australia, New Zaeland, Kenya, dan India. 


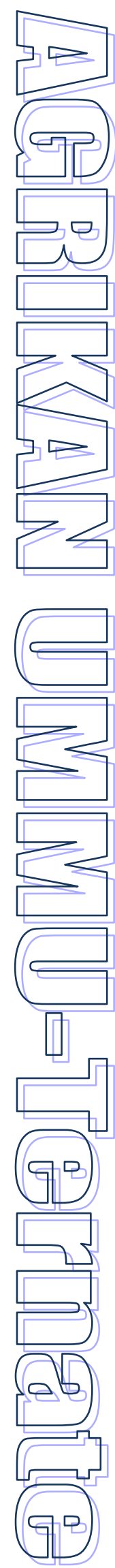

Dibanding musim panen sebelumnya, produksi markisa pada musim panen akhir 2008 turun hingga 30 persen. Rata-rata, produksi markisa Sulsel saat ini tinggal 6,4 ton hingga 7 ton. Akibat anjloknya produksi markisa Sulsel, informasi yang diperoleh Dinas Pertanian Tanaman Pangan dan Hortikultura Sulsel, sudah ada beberapa pabrik sirup markisa yang tutup karena kekurangan bahan baku. Menurut Lutfi sebenarnya jika dikembangkan secara serius, potensi markisa Sulsel sangat memadai. Cuma memang ada masalah, di mana tanaman ini tidak bisa bersaing dengan komoditas lain seperti wortel, kentang, dan sebagainya. Selain itu, masalah harga juga menjadi kendala sehingga petani tidak tertarik menanam komoditi ini. Ketika musim panen raya tiba, harganya anjlok, sementara pada saat paceklik, harganya naik.

Produsen Markisa. Propinsi Sulawesi Selatan mempunyai 30 indutri pengolahan buah markisa. Namun indutri yang produknya paling banyak beredar dan disukai masyarakat adlaah inustri pengolahan CV.Karya Kita yang berdomisili di Jln Rajawali No. 10. Dalam meningkatkan kualitas produksi perusahaan ini membuat dua merek produk sirup markissa dengan rasa yang berbeda. Markisa yang bermerek Bola Dunia rasanya dominan manis dan markisa dengan merek Bintang Dunia rasanya manis dan agak kecut. Dari kedua merek yang diperdagangkan yang banyak digemari oleh konsumen adalah sirup markisa yang bermerek Bintang Dunia, karena kekhasan rasa dari produk ini. Dalam memenuhi kepuasan konsumen dalam hal penawaran produk, maka CV Karya Kita mengemas sirup markisa dalam berbagai bentuk kemasan. Sirup markisa ada yang dikemas dalam bentuk botol dan juga kemasan siap minum (gelas plastik). Harga penjualan pada produk markisa hasil olahan CV. Karya Kita cukup mahal, karena tingginya biaya produksi. Dalam memperluas pemasaran produk markisa ini, CV. Karya Kita sudah mempunyai cabng di beberapa daerah di luar Sulawesi selatan, seperti di Jakarta, Depok, Bandung dan Surabaya.

Budidaya tanaman markisa membutuhkan 1 tahun untuk mulai berbuah. Selama ini CV. Karya Kita menerima pasokan buah markisa dari daerah Toraja dan Malakaji (Jeneponto). Meski daerah utama penghasil markisa ada di Gowa.

\subsection{Analisis pengembangan Produk}

Saat ini, produk yang sudah dikenal cukup luas di nusantara adalah produk olahan buah markisa berupa sirup. Industri markisa di Kota
Makassar memiliki potensi yang cukup besar untuk dikembangkan, karena didukung oleh bahan baku (buah markisa) dari beberapa daerah/kabupaten di Propinsi Sulawesi Selatan, seperti Kabupaten Gowa, Kabupaten Sinjai, Kabupaten Enrekang, dan Kabupaten Tana Toraja. Adanya dukungan bahan baku memberikan dampak positif terhadap munculnya industri-industri pengolalah buah markisa, baik yang berskala besar maupun yang berskala kecil (industri rumah tangga), seperti PT Markisa Segar, PT Bola Baru, PT Bola Dunia, dan PT Usti, serta sekitar 30 industri kecil lainnya (termasuk industri rumah tangga) di Kota Makassar. Adapun tujuan didirikannya industri olahan buah markissa ini adalah untuk menanggulangi permintaan masyarakat akan buah markisa dalam bentuk olahan, disamping itu juga untuk membuka lapangan kerja dan yang utamnya adalah untuk meraih keuntungan perusahaan.

Dalam jangka pendek, diperlukan pembinaan pelaku usaha yang ada pada industri ini, terutama pada industri kecil markisa. Sedangkan untuk jangka menengah, pengembangannya diarahkan pada industri makanan dan minuman markisa yang memiliki aroma dan cita rasa yang khas, terutama pada diversifikasi produk, dan pengembangan jaringan pemasaran. Sementara itu, pengembangan industri markisa jangka panjang diarahkan pada pengembangan industri farmasi dan kosmetik. Alasan pengembangan industri markisa ini pada jangka menengah adalah karena produk industri markisa di Kota Makassar baru berupa sirup markisa dan terakhir ini juga telah diproduksi dodol markisa. Oleh karena itu, diperlukan diversifikasi produk makanan dan minuman markisa yang memiliki aroma dan cita rasa yang khas, agar dapat bersaing dengan produk-produk makanan dan minuman sejenis lainnya, baik di dalam maupun di luar negeri.

Pengembangan industri markisa untuk industri farmasi dan kosmetik, lebih diarahkan pada khasiatnya bagi kesehatan manusia dan kecantikan, seperti penyakit kanker, darah tinggi, kolestrol, dan vitamin $\mathrm{C}$ anti oksidan. Buah markisa ternyata juga dapat dijadikan kosmetika lulur wajah dan badan yang bermanfaat untuk mengurangi efek penuaan dini pada kulit (BogorOnline.com).

Industri kecil pengolahan markisa di Makassar pada umumnya masih dalam bentuk industri rumah tangga, meski sudah ada dalam bentuk perusahaan. Namun, lokasi 


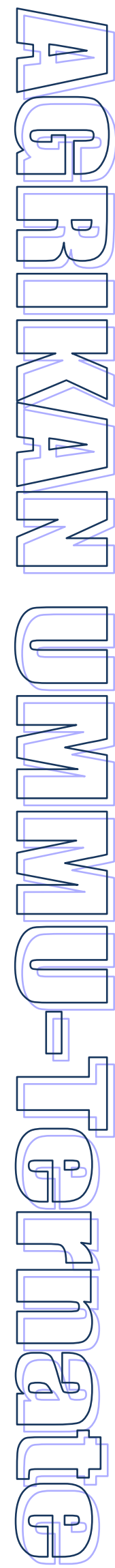

pengembangan yang paling memungkinkan adalah di kawasan industri makassar (KIMA). Di lokasi ini akan dibuat kelompok usaha/industri yang terpadu, mulai industri pengolahannya sampai pergudangannya atau distribusinya. Pengelompokan secara terpadu memungkinkan terjadinya efisiensi distribusi dan lebih memudahkan dalam penghitungan total stok untuk keperluan pemenuhan pasar.

Tabel 2, dapat dilihat bahwa matrik strategi SWOT pada pengembangan pengolahan sirup markisa di Kota Makassar yang dianalisis berdasarkan analisis SWOT pada Tabel 1.

Tabel 1. Faktor Ekternal dan Internal

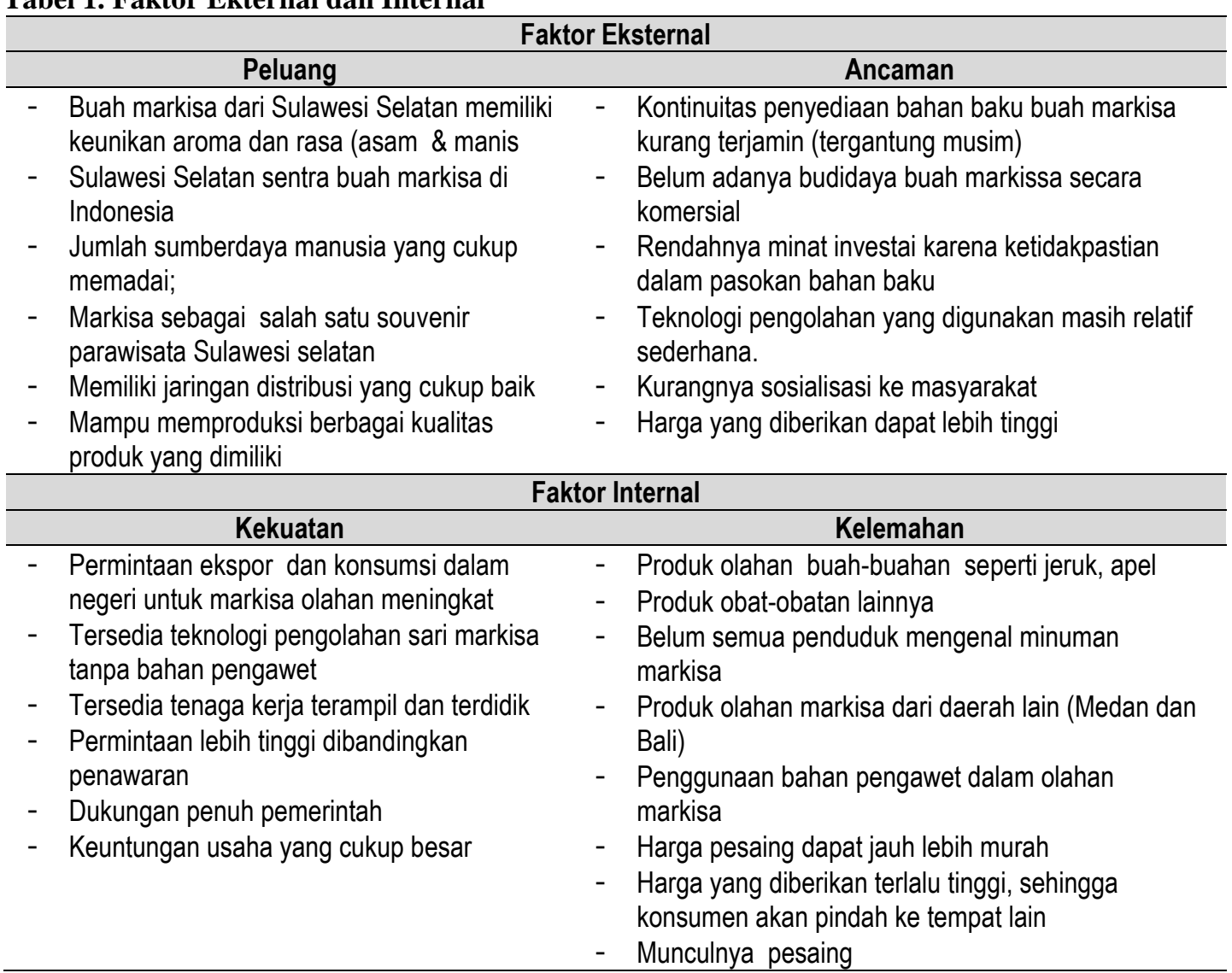

Tabel 2. Matriks Strategi SWOT industri pengolahan sirup markisa di Kota Makassar

\begin{tabular}{|c|c|c|}
\hline $\begin{array}{l}\text { Internal } \\
\text { Eksternal }\end{array}$ & Kekuatan (S) & Kelemahan (W) \\
\hline & $\underline{\text { Strategi SO }}$ & Strategi WO \\
\hline Peluang (0) & $\begin{array}{l}\text { - Meningkatkan volume produksi } \\
\text { dengan menonjolkan cita rasa } \\
\text { yang khas dan kemasan yang } \\
\text { unik untuk meraih pangsa pasar } \\
\text { yang lebih luas. } \\
\text { - } \quad \text { Perluasan jaringan distribusi } \\
\text { - } \quad \text { Meningkatkan kualitas SDM }\end{array}$ & $\begin{array}{l}\text { Meningkatkan kelembagaan industri } \\
\text { pengolahan (koperasi, asosiasi), } \\
\text { kerja sama dengan perbankan dan } \\
\text { pemerintah pusat untuk sumber } \\
\text { pendanaan dalam rangka } \\
\text { pengembangan infrastruktur } \\
\text { pengolahan markisa } \\
\text { - } \\
\text { Meningkatkan efisiensi biaya }\end{array}$ \\
\hline Ancaman (T) & $\begin{array}{l}\text { Strategi ST } \\
\text { - } \quad \text { Menetapkan strategi harga } \\
\text { - } \quad \text { Meningkatkan kualitas produk. }\end{array}$ & $\begin{array}{l}\text { Strategi WT } \\
\text { - } \text { Memantapkan rencana pemasaran } \\
\text { - Lebih memperhatikan kualitas dan } \\
\text { mutu pelayanan terhadap konsumen }\end{array}$ \\
\hline
\end{tabular}




\section{PENUTUP}

1. Markisa ungu (Passiflora edulis) adalah merupakan markisa yang dibudidayakan di Propinsi Sulawei Selatan. Karena kekhasan dari buah ini yang rasanya manis-asam dan harum. Dan juga jenis ini sesuai dengan kondisi daerah Sulawesi Selatan.

2. Permintaan akan sari buah markisa sangat tinggi, namun pasokan bahan baku yang kurang memadai membuat indusrti pengolahan harus melakukan strategi pemasaran dalam menanggulang ketersediaan produk atau adanya kontinuitas produk.

3. Berdasarkan analisis SWOT maka strategi pemasaran yang dilakukan adalah bagaimana industri menghadapi permintaan pasar, dengan melihat kekuatan (strength), Kelemahan (weakness), peluang (opportunity) dan ancaman (threath) yang di miliki oleh perusahaan.

\section{DAFTAR PUSTAKA}

Andreas, A. 2008. MARKISA Passiflora sp. www.bisnisukm.com. Diakses tanggal 04 Desember 2009.

Anonim. 2009. Produksi Buah Markisa Anjlok. www.fajar.co.id. Diakses tanggal 04 Desember 2009.

Anonim. 2008. Budidaya Markisa; Pemangkasan Perbanyak Hasil Panen. www.tosasans.com. Diakses tanggal 04 Desember 2009.

Fatkhul, M. 2009. Siapa Kreatif Dia Punya Nama. www.bisnis.com. Diakses tanggal 04 Desember 2009. 